\title{
ANALISIS EFISIENSI EKONOMI PENGGUNAAN FAKTOR-FAKTOR PRODUKSI PADA USAHATANI TEMBAKAU DI KECAMATAN GETASAN KABUPATEN SEMARANG
}

\author{
H. Hanifah, B.M. Setiawan, E. Prasetyo \\ Program Studi S1 Agribisnis Fakultas Peternakan dan Pertanian \\ Universitas Diponegoro, Semarang \\ Email : hannamukhlis@yahoo.co.id \\ Diterima 17 Februari 2017, disetujui 15 Maret 2017
}

\begin{abstract}
ABSTRAK
Tujuan penelitian ini adalah (1) menganalisis pengaruh penggunaan faktor produksi berupa luas lahan, jumah benih, tenaga kerja, pupuk kandang, pupuk ZA, pupuk NPK, pupuk $\mathrm{KNO}_{3}$ dan pestisida terhadap jumlah produksi usahatani tembakau dan (2) menganalisis tingkat efisiensi penggunaan faktor produksi usahatani tembakau secara ekonomi. Penelitian dilaksanakan pada bulan Desember 2016 di Kecamatan Getasan Kabupaten Semarang. Penelitian menggunakan metode survei dengan jumlah responden sebanyak 100 petani. Metode yang digunakan dalam pengambilan sampel adalah metode sensus. Analisis yang digunakan adalah regresi berganda dengan fungsi produksi model Cobb-Douglas dan perhitungan efisiensi ekonomi. Penelitian menunjukkan bahwa faktor produksi luas lahan, tenaga kerja dan pupuk NPK berpengaruh nyata terhadap produksi tembakau. Penggunaan faktor produksi tenaga kerja secara ekonomi belum efisien. Penggunaan faktor produksi luas lahan, jumlah benih, pupuk kandang, pupuk ZA, pupuk NPK, pupuk $\mathrm{KNO}_{3}$ dan pestisida secara ekonomi tidak efisien.
\end{abstract}

Kata Kunci : efisiensi, produksi, faktor produksi, tembakau, usahatani

\begin{abstract}
The purpose of this study were to analyze the effect of the use of production factors such as land, number of seeds, labor, manure, ZA fertilizer, NPK fertilizer, $\mathrm{KNO}_{3}$ fertilizer and pesticides to total farm production of tobacco and analyze the efficiency in technically and economically of the use of production factors of farming tobacco in the Getasan District, Semarang Regency. The research was conducted at December 2016 in Getasan District. The method used in this research was survey method with the number of respondents as many as 100 farmers. The method used in the sampling was census method. The analysis used was multiple regression of Cobb-Douglas production function models and economic efficiency calculation. The results showed that the production factors of land, labor and NPK fertilizer had a significant effect on tobacco production. The use of production factors of labor was economically inefficient. The use of land, number of seeds, manure, ZA fertilizers, NPK fertilizers, $\mathrm{KNO}_{3}$ fertilizers, and pesticides was economically inefficient.
\end{abstract}

Keywords : efficiency, farming, production, production factors, tobacco. 


\section{PENDAHULUAN}

Tembakau merupakan salah satu komoditas yang diunggulkan dalam sub sektor perkebunan di Indonesia.. Komoditi tembakau mempunyai arti yang penting, tidak hanya sebagai sumber pendapatan bagi para petani, tetapi juga bagi Negara. Usaha pertanian tembakau merupakan usaha padat karya (Hanum, 2008). Kabupaten Semarang merupakan salah satu kabupaten penghasil tembakau di Provinsi Jawa Tengah dengan luas perkebunan tembakau sebesar $988 \mathrm{Ha}$ (BPS Kabupaten Semarang, 2014). Tanaman tembakau yang ditanam di Kecamatan Getasan adalah tembakau varietas Kemloko, Gober/Andong.

Produktivitas usahatani tembakau dipengaruhi oleh berbagai faktor terutama faktor produksi. Penggunaan faktor produksi harus sesuai dan tepat. Faktor-faktor produksi akan menentukan besar kecilnya produksi yang dihasilkan (Cahyono, 2005). Faktor produksi tembakau adalah luas lahan, benih tembakau, pupuk sesuai kebutuhan nutrisi tanaman, tenaga kerja, modal dan pestisida (Mamat et al., 2006).Penggunaan faktor produksi harus efisien secara teknis dan ekonomis sehingga penggunaan faktor produksi tidak berlebihan dan dapat meningkatkan penerimaan bagi petani.

Tujuan dari penelitian ini adalah (1) menganalisis pengaruh penggunaan faktorfaktor produksi yang meliputi luas lahan, jumlah benih, tenaga kerja, pupuk kandang, pupuk ZA, pupuk NPK fertila, pupuk $\mathrm{KNO}_{3}$ dan pestisida terhadap produksi usahatani tembakau, dan (2) menganalisis efisiensi ekonomi penggunaan faktor-faktor produksi pada usahatani tembakau di Kecamatan Getasan Kabupaten Semarang. Manfaat dari penelitian ini diharapkan dapat menjadi referensi bagi petani dalam penggunaan faktor produksi secara efisien agar didapatkan produksi yang maksimal. Juga, sebagai referensi bagi pemerintah daerah setempat dan dinas pertanian terkait dalam menentukan kebijakan pengembangan usahatani tembakau rakyat dan sebagai bahan referensi bagi penelitian selanjutnya pada bidang yang sama.

\section{METODE PENELITIAN}

\section{Waktu dan Lokasi Penelitian}

Penelitian dilaksanakan pada bulan Desember 2016 di Kecamatan Getasan Kabupaten Semarang. Lokasi penelitian ditentukan secara purposive yaitu penentuan lokasi yang berdasarkan dengan kriteriakriteria tertentu yang ditetapkan berdasarkan tujuan penelitian (Sugiyono, 2008). Kabupaten Semarang merupakan kabupaten penghasil tembakau terbesar ketiga di Provinsi Jawa Tengah setelah Kabupaten Temanggung dan Kendal, mempunyai luas perkebunan tembakau 988 Ha. Selanjutnya, Kecamatan Getasan dipilih karena merupakan kecamatan yang memiliki luas lahan perkebunan tembakau terluas di Kabupaten Semarang yakni seluas $853 \mathrm{Ha}(86,34 \%)$ (BPS Kabupaten Semarang, 2014).

\section{Metode Penelitian dan Pengambilan Sampel}

Penelitian dilakukan dengan metode survei. Metode survei adalah penelitian yang mengambil sampel dari satu populasi dan menggunakan kuesioner sebagai alat pengumpulan data yang pokok (Singarimbun dan Effendi, 2006). Populasi dalam penelitian ini adalah petani tembakau kemitraan di Kecamatan Getasan Kabupaten Semarang berjumlah 100 orang. Sampel pada penelitian ini diambil secara sensus. Sensus adalah cara pengambilan sampel yang menjadikan semua anggota populasi sebagai sampel (Martono, 2010).

\section{Pengumpulan Data}

Data yang digunakan dalam penelitian ini adalah data primer dan data sekunder. Data primer diperoleh dari responden dengan wawancara menggunakan panduan kuesioner. Kuesioner berisi data tentang identitas responden, luas lahan, penggunaan jumlah benih, penggunaan pupuk dan pestisida pada ushatani tembakau di Kecamatan Getasan. 
Data sekunder diambil dari sumber atau instansi-instansi terkait yakni Badan Pusat Statistik Kabupaten Semarang, Dinas Perkebunan Provinsi Jawa Tengah, Dinas Perkebunan Jawa Timur, publikasi dari penelitian yang sudah dilakukan sebelumnya serta dari pustaka lain yang berhubungan dengan penelitian ini.

\section{Metode Analisis Data}

Data setelah ditabulasi selanjutnya dilakukan uji multikolinieritas untuk mengetahui adanya korelasi antar variabel bebas, data dengan nilai $\mathrm{VIF}<10$ dinyatakan tidak terjadi multikolinieritas (Wiratna dan Endrayanto, 2012). Uji normalitas untuk mengetahui data berdistribusi normal atau tidak dengan kriteria pengujian angka signifikansi $>0,05$, uji Autokorelasi menggunakan nilai DurbinWatson (DW) yang menunjukkan nilai residual (prediction error) dengan kriteria pengujian $-2<\mathrm{dw}<2$ (Gujarati, 2010), uji heteroskedastisitas bertujuan untuk mengetahui adanya varians dalam suatu model regresi dapat diketahui dari grafik scatterplot yang menunjukkan titik-titik berpola (Ghozali, 2005).

Model yang digunakan untuk menggambarkan pengaruh kuantitas penggunaan faktor-faktor produksi tembakau adalah fungsi produksi model Cobb-Douglas. Fungsi produksi model Cobb-Douglas yang digunakan dalam bentuk persamaan sebagai berikut (Soekartawi, 2002):

$\mathrm{Y}=\mathrm{aX} 1^{\beta 1} \cdot \mathrm{X} 2^{\beta 2} \cdot \mathrm{X} 3^{\beta 3} \cdot \mathrm{X} 4^{\beta 4} \cdot \mathrm{X} 5^{\beta 5} \cdot \mathrm{X} 6^{\beta 6}$. $\mathrm{X} 7^{\beta 7} \cdot \mathrm{X}^{\beta 8} \cdot \mathrm{e}^{\mu}$

Persamaan (1) dapat ditransformasikan dalam bentuk logaritma natural sebagai berikut :

$\operatorname{LnY}=\operatorname{Lna}+\beta 1 \operatorname{LnX} 1+\beta 2 \operatorname{LnX} 2+\beta 3 \operatorname{LnX} 3+$ $\beta 4 \operatorname{LnX} 4+\beta 5 \operatorname{LnX} 5+\beta 6 \operatorname{LnX} 6+\beta 7 \operatorname{LnX} 7+$ $\beta 8 \operatorname{LnX} 8+\mathrm{e} \mu$

Keterangan :

$\mathrm{Y}=$ jumlah produksi tembakau $(\mathrm{kg} /$ masa tanam)

$\mathrm{X} 1=$ luas lahan $\left(\mathrm{m}^{2} /\right.$ masa tanam $)$

$\mathrm{X} 2=$ jumlah benih (gram/ masa tanam)

$\mathrm{X} 3$ = jumlah tenaga kerja $\mathrm{HOK} /$ masa tanam)

$\mathrm{X} 4=$ jumlah pupuk kandang $(\mathrm{kg} /$ masa tanam $)$

$\mathrm{X} 5$ = jumlah pupuk $\mathrm{ZA}(\mathrm{kg} /$ masa tanam $)$
X6 = jumlah pupuk NPK Fertila $(\mathrm{kg} /$ masa tanam)

$\mathrm{X} 7=$ jumlah pupuk $\mathrm{KNO}_{3}(\mathrm{~kg} /$ masa tanam $)$

$\mathrm{X} 8$ = jumlah pestisida (liter/ masa tanam)

B1- $\beta 8=$ besaran yang akan diduga

$\mathrm{e}=$ kesalahan (disturbance term)

Uji $\mathrm{F}$ dan uji t dilakukan untuk melihat variabel independent secara keseluruhan dan parsial terhadap variabel dependent (Ghozali, 2005). Pengujian ini dilakukan dengan membandingkan nilai $\mathrm{F}$ hitung dengan $\mathrm{F}$ tabel serta $\mathrm{t}$ hitung dengan $\mathrm{t}$ tabel. Jika nilai $\mathrm{t}$ hitung $>\mathrm{t}$ tabel maka menunjukkan adanya pengaruh variabel bebas terhadap variabel terikat (Ramadhani, 2011).

Efisiensi ekonomi tercapai bila nilai produk marjinal (NPM) sama dengan Biaya Korbanan Marjinal (BKM) sehingga dapat dirumuskan Efisiensi Ekonomi (EE) sebagai berikut:

Efisiensi Ekonomi $=\frac{\text { NPMxi }}{\text { BKMxi }}=\frac{\text { Bxi.Y } / \text { Xi.Py }}{\text { Pxi }}$

atau $\underline{\text { MPP.Py }}=1$

Pxi

Produk marjinal (MPP) dapat dihitung dari fungsi produksi model Cobb Douglas dengan cara koefisien regresi $(\beta)$ pada model Cobb-Douglas dikalikan Y/X dan perhitungan nilai efisiensi dilakukan setiap faktor produksi dan tidak secara bersamaan (Soekartawi,2002). Kriteria pengujian sebagai berikut :

a. Penggunaan faktor produksi tidak efisien jika $(\mathrm{MPPxPy}) / \mathrm{Pxi}<1$, input harus dikurangi

b.Penggunaan faktor produksi sudah efisien jika (MPPxPy)/Pxi = 1, input sesuai

c.Penggunaan faktor produksi belum efisien jika (MPPxPy)/Pxi> 1,input perlu ditambah

\section{HASIL DAN PEMBAHASAN}

\section{Keadaan Umum Daerah Penelitian}

Kabupaten Semarang merupakan salah satu kabupaten yang terletak di Provinsi Jawa Tengah yang terdiri atas 19 kecamatan. Kabupaten Semarang merupakan salah satu kabupaten penghasil tembakau di Provinsi 
Jawa Tengah, salah satu kecamatan yang memproduksi tembakau adalah Kecamatan Getasan. Kecamatan Getasan memiliki luas lahan perkebunan tembakau terluas menurut data BPS Kabupaten Semarang (2016) yakni seluas $1.170 \mathrm{Ha}$ lahan tanaman belum menghasilkan (TBM) dan 936 Ha lahan tanaman menghasilkan (TM). Tanaman tembakau yang ditanam di Kecamatan Getasan adalah tembakau varietas Kemloko, Gober/Andong. Perkebunan tembakau di Kecamatan Getasan merupakan perkebunan rakyat, dikelola oleh petani yang tergabung dalam kelompok tani dan bermitra dengan perusahaan rokok Djarum. Pola kemitraan yang dijalin antara petani tembakau di Kecamatan getasan dan PT Djarum adalah pola kemitraan inti-plasma.

\section{Identitas Responden}

Identitas responden dapat dilihat pada Tabel 1. Kisaran umur responden penelitian pada umur produktif yaitu 35-44 tahun. Kondisi umur yang masih produktif memungkinkan seseorang dapat bekerja dengan baik dan maksimal. Umur dapat menentukan prestasi kerja dan menentukan tingkat pemahaman seseorang (Soekartawi, 2002). Pengalaman berusahatani yang dimiliki sebagian besar responden adalah 020 tahun. Pengalaman berusahatani dapat berpengaruh positif terhadap keberlangsungan usahatani sebab semakin bertambah pengalaman usahatani yang dimiliki petani maka petani semakin berani dalam mengambil resiko dalam berusahatani (Hermaningsih, 2014).

Tabel 1. Identitas Responden

\begin{tabular}{llcc}
\hline \hline No & Indikator & $\begin{array}{c}\text { Jumlah } \\
\text { (orang) }\end{array}$ & $\begin{array}{c}\text { Presentase } \\
(\%)\end{array}$ \\
\hline 1 Umur (tahun) & & 13 \\
$25-34$ & 13 & 38 \\
$35-44$ & 38 & 31 \\
$45-54$ & 31 & 18 \\
$55-64$ & 18 & \\
2 Lama Usahatani (tahun) & & 17 \\
$<10$ & 17 & 38 \\
$11-20$ & 38 & 17 \\
$21-30$ & 17 & 23 \\
$31-40$ & 23 & 5 \\
$>41$ & 5 & 69 \\
3 Pendidikan & & 23 \\
SD & 69 & 7 \\
SMP & 23 & 1 \\
SMA & 7 & \\
Pendidikan Tinggi & 1 & 27 \\
Jumlah Anggota Keluarga (orang) & & 67 \\
$0-3$ & 27 & 6 \\
4-7 & 67 & \\
$8-11$ & 6 & 35 \\
Luas Lahan yang dimiliki (m ${ }^{2}$ ) & & 45 \\
1000-2999 & 35 & 73 \\
$3000-5999$ & 45 & \\
$6000-8999$ & 13 & \\
$9000-12999$ & 7 & \\
\hline
\end{tabular}

Sumber : Data Primer Penelitian, 2016. 
Tingkat pendidikan responden sebagian besar $(69 \%)$ adalah tamat SD. Tingkat pendidikan petani tergolong rendah sehingga dalam melakukan usahataninya petani cenderung bersikap selektif terhadap inovasi karena tingkat pendidikan petani yang rendah menjadikan petani memilih sikap safety first dan mengutamakan teknik yang sudah dipahami (Hermaningsih, 2014). Jumlah anggota keluarga responden rata-rata sebanyak 4-7 orang. Jumlah anggota keluarga dapat mempengaruhi sikap petani, semakin besar jumlah anggota keluarga yang dimiliki maka petani semakin tidak ingin mengambil risiko terutama dalam mencoba inovasi pertanian yang baru (Soekartawi, 2002).

\section{Faktor-Faktor yang mempengaruhi Produksi}

Hasil penelitian menunjukkan nilai koefisien regresi $(\beta)$ untuk masing-masing faktor produksi pada Tabel 2. Persamaan fungsi produksi dituliskan sebagai berikut:

$\operatorname{LnY}=-\operatorname{Ln} 1,036+0,807 \operatorname{LnX}_{1}-0,011 \operatorname{LnX}_{2}$ $+0,249 \operatorname{LnX}_{3}-0,022 \operatorname{LnX}_{4}$ $-0,040 \operatorname{Ln} X_{5}-0,096 \operatorname{Ln} X_{6}+0,009 \operatorname{Ln} X_{7}-$ $0,035 \operatorname{Ln} X_{8}$

Pengaruh penggunaan faktor produksi usahatani tembakau terhadap jumlah produksi tembakau di Kecamatan Getasan Kabupaten Semarang dapat diketahui melalui nilai adjusted $R$ square uji $\mathrm{F}$ dan uji t pada Tabel 2 yang dapat dijelaskan sebagai berikut:

a. Berdasarkan analisis diperoleh nilai adjusted $\mathrm{R}$ square sebesar 0,908 artinya 90,8\% menjelaskan faktorproduksi luas lahan, jumlah benih, tenaga kerja, pupuk kandang, pupuk ZA, pupuk NPK Fertila, pupuk $\mathrm{KNO}_{3}$ dan pestisida sedangkan 9,2\% dipengaruhi oleh faktor lain yang tidak dimasukan dalam model regresi. Hal ini sesuai dengan pendapat Ramadhani (2011) bahwa semakin besar nilai $\mathrm{R}^{2}$ mendekati nilai satu, semakin baik hasil regresi tersebut sehingga variabel independent secara keseluruhan dapat menjelaskan variabel dependent.

b. Berdasarkan analisis uji $\mathrm{F}$, diperoleh hasil yaitu nilai signifikansi sebesar 0,000. Nilai signifikansi menunjukkan nilai $\leq 0,05$ sehingga $\mathrm{H} 1$ diterima dan $\mathrm{H} 0$ ditolak artinya, faktor produksi berupa luas lahan, jumlah benih, tenaga kerja, pupuk kandang, pupuk ZA, pupuk NPK Fertila, pupuk $\mathrm{KNO}_{3}$ dan pestisida berpengaruh sangat nyata terhadap hasil produksi tembakau di Kecamatan Getasan Kabupaten Semarang.

c. Berdasarkan analisis uji $\mathrm{t}$ didapat nilai signifikansi variabel luas lahan, tenaga kerja dan pupuk NPK fertila sebesar 0,000; 0,000;

Tabel 2.Hasil analisis faktor-faktor yang mempengaruhi produksi

\begin{tabular}{lccl}
\hline \hline Variabel & Koefisien Regresi & t Hitung & Sign. \\
\hline Konstanta & $-1,036$ & $-1,810$ & 0,074 \\
X1 Luas lahan & 0,807 & 13,325 & $0,000^{* *}$ \\
X2 Jumlah benih & $-0,011$ & $-0,277$ & 0,782 \\
X3 Tenaga kerja & 0,249 & 3,892 & $0,000^{* *}$ \\
X4 Pupuk kandang & $-0,022$ & $-0,502$ & 0,617 \\
X5 Pupuk ZA & $-0,040$ & $-1,276$ & 0,205 \\
X6 Pupuk NPK Fertila & $-0,096$ & $-2,325$ & $0,022^{*}$ \\
X7 Pupuk KNO & 0,009 & 0,275 & 0,784 \\
X8 Pestisida & $-0,035$ & $-0,965$ & 0,337 \\
\hline Adjusted R square & & & 0,908 \\
F hitung & 68,576 & & $0,000^{*}$ \\
\hline
\end{tabular}

Sumber : Data Primer Penelitian, 2016.

Keterangan :

$*) \quad=$ Signifikan pada tingkat kepercayaan $\alpha=5 \%$

**) $=$ Signifikan pada tingkat kepercayaan $\alpha=1 \%$ 
dan 0,022 hal ini menunjukkan bahwa secara parsial factor-faktor produksi tersebut mempengaruhi jumlah produksi tembakau. Nilai signifikansi $\leq 0,05$ menunjukkan secara parsial variabel luas lahan, tenaga kerja dan pupuk NPK fertila menunjukkan pengaruh yang signifikan terhadap produksi tembakau. Faktor produksi benih, pupuk kandang, pupuk ZA, pupuk $\mathrm{KNO}_{3}$ dan pestisida tidak menunjukkan pengaruh nyata terhadap produksi.

\section{Efisiensi Ekonomi Penggunaan Faktor Produksi}

Perhitungan nilai efisiensi dilakukan pada masing-masing faktor produksi dan tidak secara bersamaan. Nilai koefisien regresi (B), nilai produk marjinal (NPM), nilai korbanan marjinal (BKM) dan hasil perhitungan efisiensi ekonomi dapat dilihat pada Tabel 3.

Berdasarkan Tabel 3 diperoleh nilai koefisien regresi $(\beta)$ masing-masing faktor produksi $\leq 1$. Nilai koefisien regresi tersebut menggambarkan nilai efisiensi secara teknis, artinya penggunaan faktor produksi usahatani tembakau tidak efisien secara teknis. Menurut Budiono (2002) kriteria penilaian efisiensi secara teknis dapat dilihat dari besarnya elastisitas produksi atau nilai koefisien regresi yang diperoleh. Ketentuan efisien jika nilai koefisien sama dengan satu. Berdasarkan nilai efisiensi ekonomi yang diperoleh, diperoleh hasil bahwa penggunaan faktor produksi tenaga kerja belum efisien $(>1)$ yakni sebesar 9,71 . Nilai efisiensi ekonomi faktor produksi luas lahan, jumlah benih, pupuk kandang, pupuk ZA, pupuk NPK fertila, pupuk $\mathrm{KNO}_{3}$ dan pestisida tidak efisien karena nilai efisiensinya $<1$. Efisiensi ekonomi tercapai bila nilai produk marjinal (NPM) sama dengan Biaya Korbanan Marjinal (BKM) (Soekartawi, 2002).

Nilai efisiensi ekonomi yang diperoleh dari faktor produksi luas lahan adalah sebesar 0,72. Nilai efisiensi kurang dari satu artinya penggunaan faktor produksi luas lahan tidak efisien secara ekonomi. Hal tersebut disebabkan oleh nilai biaya korbanan marginal (BKM) lahan terlalu tinggi. Untuk mencapai nilai efisiensi luas lahan secara ekonomi, perlu dilakukan pengurangan penggunaan luas lahan. Pengurangan luas lahan bertujuan untuk mengoptimalkan penggunaan lahan dan faktor produksi sehingga pengurangan luas lahan dapat berdampak pada peningkatan produktivitas petani. Pengurangan luas lahan yang digunakan disesuaikan dengan jarak tanam tanaman, menurut Akbar et al. (2011) bahwa pengaturan jarak tanam yang sesuai dapat mengurangi terjadinya kompetisi terhadap faktor-faktor tumbuh tanaman yang mempengaruhi produktivitas tanaman.

Tabel 3. Perhitungan Efisiensi Ekonomi Usahatani Tembakau di Kecamatan Getasan Kabupaten Semarang

\begin{tabular}{|c|c|c|c|c|c|}
\hline Variabel & $\mathrm{B}$ & NPM & $\mathrm{BKM}$ & Efisiensi & Keterangan \\
\hline Luas Lahan & 0,807 & 36219,653 & 50000 & 0,72 & $\overline{\mathrm{TE}}$ \\
\hline Jumlah Benih & $-0,011$ & $-285724,065$ & 10000 & $-28,57$ & $\mathrm{TE}$ \\
\hline Tenaga Kerja & 0,249 & 485401,587 & 50000 & 9,71 & $\mathrm{BE}$ \\
\hline Pupuk Kandang & $-0,022$ & $-1012,154$ & 400 & $-2,53$ & TE \\
\hline Pupuk ZA & $-0,040$ & $-100817,109$ & 4000 & $-25,20$ & TE \\
\hline $\begin{array}{l}\text { Pupuk NPK } \\
\text { Fertila }\end{array}$ & $-0,096$ & $-151359,378$ & 12696 & $-11,92$ & TE \\
\hline Pupuk $\mathrm{KNO}_{3}$ & 0,009 & 11201,275 & 19638 & 0,57 & TE \\
\hline Pestisida & $-0,035$ & $-2281572,642$ & 230000 & $-9,92$ & $\mathrm{TE}$ \\
\hline
\end{tabular}

Sumber: Data Primer Penelitian, 2016.

Keterangan :

$\mathrm{BE}=$ Belum efisien

$\mathrm{TE}=$ Tidak efisien 
Nilai efisiensi ekonomi yang diperoleh dari faktor produksi jumlah benih adalah sebesar -28,57. Nilai efisiensi kurang dari satu artinya penggunaan faktor produksi jumlah benih tidak efisien secara ekonomi. Hal tersebut disebabkan oleh nilai biaya korbanan marjinal (BKM) yakni harga benih per gram di Kecamatan Getasan lebih tinggi dibandingkan dengan nilai produk marjinalnya. Jumlah benih yang digunakan tidak sesuai sehingga untuk mencapai nilai efisiensi perlu dilakukan pengurangan penggunaan jumlah benih. Kelebihan jumlah benih menyebabkan tanaman tumbuh terlalu rapat, jarak tanam yang tidak sesuai mengakibatkan pertumbuhan kurang baik. Menurut Estariza et al, (2013) penggunaan jarak tanam yang sesuai dapat menunjukan nilai efisiensi secara teknis yang baik sehingga tanaman dapat tumbuh dengan baik.

Faktor produksi tenaga kerja mempunyai nilai efisiensi ekonomi sebesar 9,71. Nilai efisiensi menunjukkan angka lebih besar dari satu artinya penggunaan faktor produksi tenaga kerja belum efisien secara ekonomi, karena nilai BKM tenaga kerja di Kecamatan Getasan lebih rendah dari nilai produk marginalnya. Untuk mencapai nilai efisiensi secara ekonomi perlu dilakukan peningkatan nilai biaya korbanan marjinal (BKM). Peningkatan nilai BKM tenaga kerja tersebut dapat dilakukan dengan menambah upah tenaga kerja sampai batas perbandingan sama dengan satu. Jumlah tenaga kerja tidak berpengaruh terhadap produksi tembakau, implikasinya penambahan tenaga kerja tidak akan menyebabkan peningkatan jumlah produksi tembakau. Fauziyah (2010) menyatakan bahwa kelebihan jumlah tenaga kerja tidak berdampak pada hasil produksi namun kelebihan tenaga kerja berdampak pada analisis ekonomi berupa keuntungan yang diterima petani, semakin tinggi jumlah tenaga kerja yang dimiliki maka upah yang diterima petani semakin rendah.

Faktor produksi pupuk kandang mempunyai nilai efisiensi ekonomi yang sebesar -2,53. Nilai efisiensi kurang dari satu artinya penggunaan faktor produksi pupuk kandang tidak efisien secara ekonomi. Hal tersebut disebabkan oleh nilai biaya korbanan marjinal (BKM) pupuk kandang di Kecamatan Getasan lebih tinggi dibandingkan dengan nilai produk marjinalnya. Penggunaan pupuk kandang pada usahatani tembakau melebihi dosis yang dianjurkan sehingga untuk mencapai nilai efisiensi perlu dilakukan pengurangan jumlah penggunaan pupuk kandang. Penggunaan pupuk kandang yang berlebihan dapat berdampak pada tanaman tembakau terutama jika pupuk kandang yang digunakan belum terfermentasi secara sempurna. Menurut Cahyono (2005) penggunaan pupuk kandang yang belum matang atau terfermentasi sempurna dapat menyebabkan perkembangan jamur pada tanah sehingga dapat menyebabkan penyakit akar pada tanaman tembakau seperti penyakit lanas dan rebah kecambah.

Nilai efisiensi ekonomi dari faktor produksi pupuk ZA dan pupuk NPK Fertila adalah sebesar $-25,20$ dan $-11,92$. Nilai efisiensi kurang dari satu artinya penggunaan faktor produksi pupuk ZA tidak efisien secara ekonomi. Hal tersebut disebabkan oleh nilai biaya korbanan marjinal (BKM) pupuk ZA dan NPK lebih tinggi dibandingkan dengan nilai produk marjinalnya. Penggunaan pupuk ZA dan pupuk NPK Fertila pada usahatani tembakau melebihi dosis yang dianjurkan sehingga untuk mencapai nilai efisiensi perlu dilakukan pengurangan jumlah penggunaan. Pemberian pupuk ZA dan NPK yang berlebihan dapat berakibat pada kelebihan unsur nitrogen pada tanah yang dapat menyebabkan hama pada tanaman. Hal ini sesuai dengan pendapat Hanum (2008), pemberian pupuk nitrogen yang berlebihan dapat memacu perkembangan populasi hama terutama kutu tembakau.

Nilai efisiensi ekonomi dari faktor produksi pupuk $\mathrm{KNO}_{3}$ adalah sebesar 0,57. Nilai efisiensi kurang dari satu artinya penggunaan faktor produksi pupuk $\mathrm{KNO}_{3}$ tidak efisien secara ekonomi. Hal tersebut karena nilai biaya korbanan marjinal (BKM) pupuk $\mathrm{KNO}_{3}$ lebih tinggi dibandingkan 
dengan nilai produk marjinalnya. Penggunaan pupuk $\mathrm{KNO}_{3}$ pada usahatani tembakau melebihi dosis yang dianjurkan sehingga perlu dilakukan pengurangan jumlah penggunaan. Kelebihan penggunaan pupuk pada tanaman tembakau dapat menyebabkan penurunan produktivitas. Selaras dengan pendapat Cahyono (2005) bahwa pemberian pupuk $\mathrm{KNO}_{3}$ bertujuan untuk pemenuhan unsur nitrogen dan kalium namun kelebihan unsur nitrogen seringkali menyebabkan pertumbuhan bakteri penyebab busuk akar sehingga tanaman mudah rebah dan mati.

Nilai efisiensi ekonomi dari faktor produksi pestisida adalah sebesar $-9,92$. Nilai efisiensi kurang dari satu artinya penggunaan faktor produksi pestisida tidak efisien secara ekonomi. Nilai biaya korbanan marjinal (BKM) pestisida lebih tinggi dibandingkan dengan nilai produk marjinalnya. Penggunaan pestisida oleh petani pada usahatani tembakau melebihi dosis yang dianjurkan sehingga perlu dilakukan pengurangan jumlah pestisida yang digunakan. Penggunaan pestisida yang berlebihan dapat mengganggu pertumbuhan tanaman. Menurut Djojosumarto (2008) pestisida yang hendak digunakan harus dipertimbangkan berdasarkan ketepatannya meliputi tepat guna, waktu, jenis dan dosisnya sebab penggunaan pestisida yang tidak sesuai dapat berdampak pada tanaman serta keseimbangan lingkungan.

\section{SIMPULAN DAN SARAN}

\section{Simpulan}

Berdasarkan penelitian yang telah dilakukan dapat disimpulkan bahwa 90,8\% dapat menjelaskan faktor produksi luas lahan, jumlah benih, tenaga kerja, pupuk kandang, pupuk ZA, pupuk NPK Fertila, pupuk $\mathrm{KNo}_{3}$ dan pestisida terhadap jumlah produksi tembakau. Sedangkan 9,2\% dijelaskan oleh faktor lain yang tidak dimasukkan dalam model regresi. Faktor produksi yang paling berpangaruh adalah luas lahan, tenaga kerja dan pupuk NPK fertila sedangkan faktor produksi jumlah benih,pupuk kandang, pupuk
ZA, pupuk $\mathrm{KNO}_{3}$ dan pestisida tidak berpengaruh nyata terhadap produksi tembakau di Kecamata Getasan Kabupaten Semarang. Penggunaan faktor produksi luas lahan, jumlah benih, pupuk kandang, pupuk ZA, pupuk NPK fertila, pupuk $\mathrm{KNO}_{3}$ dan pestisida tidak efisien secara ekonomi sedangkan faktor produksi tenaga kerja belum efisien secara ekonomi.

\section{Saran}

Petani kemitraan di Kecamatan Getasan dapat meningkatkan efisiensi usahatani tembakau dengan meningkatkan produktivitas secara teknis dan ekonomis. Secara teknis dapat dilakukan dengan penggunaan faktorfaktor produksi secara tepat dan sesuai dosis yang dianjurkan. Secara ekonomi nilai biaya korbanan marginal pada faktor produksi luas lahan, benih, pupuk kandang, pupuk ZA, pupuk NPK fertila, pupuk $\mathrm{KNO}_{3}$ dan pestisida dapat dikurangi. Upah tenaga kerja di Kecamatan Getasan masih memungkinkan untuk ditingkatkan sesuai dengan nilai efisiensi ekonomi usahatani tembakau. Aplikasi teknologi perlu ditingkatkan agar penggunaan faktor produksi lebih efisien secara teknis dan ekonomi.

\section{DAFTAR PUSTAKA}

Akbar,B. M. Muryono, F. Hendrayana. 2011. Pengaruh Kerapatan Terhadap Pertumbuhan Dan Produktivitas Tanaman Tembakau (Nicotiana Tabacum) Varietas Serumpung dan Semboja. Institut Teknologi Surabaya, Surabaya. http://digilib.its.ac.id/public/ITS-paper27250-1507100013-paper-bari.pdf

BPS Kabupaten Semarang. 2014. Luas/Banyaknya Pohon Tanaman Perkebunan Rakyat di Kabupaten Semarang Menurut Kecamatan Tahun 2014. https://semarangkab.bps.go.id/ linkTabelStatis/view/id/85.

Budiono. 2002. Ekonomi Mikro Seri Sinopsis: Pengantar Ilmu Ekonomi No.1. BPFE, Yogyakarta. 
Cahyono, B. 2005. Tembakau: Budidaya dan Analisis Usaha Tani. Kanisius, Yogyakarta.

Djojosumarto, P, 2008. Pestisida dan Aplikasinya, PT. Agromedia Pustaka, Jakarta.

Fauziyah, E. 2010. Analisis efisiensi teknis usahatani tembakau (suatu kajian dengan menggunakan fungsi produksi frontier stokhastik). Jurnal Embriyo. 7 (1): 1-7

Ghozali, I. 2005. Aplikasi Analisis Multivariate dengan Program SPSS. Badan Penerbit Universitas Diponegoro, Semarang.

Gujarati, D. 2010. Ekonometrika Dasar. Terjemahan Sumarno Zain. Erlangga, Jakarta.

Hanum, C. 2008. Teknik Budidaya Tanaman Jilid 3. Departemen Pendidikan Nasional. Jakarta.

Hermaningsih, H. 2014. Pengaruh perubahan iklim terhadap perilaku petani tembakau di Kabupaten Jember. J. Matematika, Saint dan Teknologi 1 (15): 42-51.
Mamat H.S., S.R.P. Sitorus , H. Hardjomidjojo, dan A.K. Seta. 2006. Analisis mutu, produktivitas, keberlanjutan dan arahan pengembangan usahatani tembakau di Kabupaten Temanggung, Jawa Tengah. J. Littri 12 (4): 146 - 153.

Martono, N. 2010. Metode Penelitian Kuantitatif Analisis Isi dan Analisis Data Sekunder. PT Raja Grafindo Persada, Jakarta.

Ramadhani, Y. 2011. Analisis efisiensi, skala dan elastisitas produksi dengan pendekatan Cobb-Douglas dan regresi berganda. J. Teknologi 4 (1): 53-61.

Singarimbun, M. dan S. Effendi. 2006. Metode Penelitian Survei. LP3S, Jakarta.

Soekartawi. 2002. Prinsip Ekonomi Pertanian. Rajawali Press. Jakarta.

Sugiyono. (2008). Metode Penelitian Kuantitatif, Kualitatif dan R\&D. Alfabeta. Bandung.

Wiratna, S dan P. Endrayanto. 2012. Statistik Untuk Penelitian. Graha Ilmu. Jakarta. 